Formatif: Jurnal Ilmiah Pendidikan MIPA

Vol. 9, No. 3, September 2019, pp. 229-244

p-ISSN: 2088-351X

e-ISSN: 2502-5457

DOI: http://dx.doi.org/10.30998/formatif.v9i3.3651

\title{
Improving Coastal Children Eco-Literacy in Environmental Learning Through Mangroves Storytelling
}

\author{
Novi Utami Rosyid (*) \\ Pascasarjana Universitas Negeri Jakarta \\ Budiaman \\ Pascasarjana Universitas Negeri Jakarta \\ Uswatun Hasanah \\ Pascasarjana Universitas Negeri Jakarta
}

Received: April 25, 2019

Revised: July 3, 2019

Accepted: July 22, 2019

\begin{abstract}
The objective of this research was to determine the level of coastal children eco-literacy by using storytelling about the role of mangroves for coastal communities in Serang Regency - Banten. The research methodology was classroom action research (CAR). The implementation of classroom action research was conducted of two cycles. There was cycle I and cycle II, each cycle consisted of two meetings. This research involved third-grade students which consisted of 30 students in SDN Cerocoh, Serang Regency - Banten. The instrument of the research was data collecting technique, the data were observation, tests (pre-test and post-tests), and documentation. The result of this research showed that there was a significant difference in the students' eco-literacy in pre-test and post-test after learning environmental education with mangrove storytelling. The average score of pre-test was $48.52 \%$, while, after giving treatment in cycle I, the students average score in post-test I was $68.94 \%$. Then, after giving treatment in cycle II, the students' average score in post-test II was $87.17 \%$. Based on the data the researcher concluded that there was the improvement coastal student eco-literacy by using mangrove storytelling in teaching environmental education at environmental thematic subject.

Keywords: Coastal Coastal Children, Eco-literacy, Environmental Education; Mangroves Storytelling
\end{abstract}

(*) Corresponding Author: noviutamir_s2pklh2017@unj.ac.id / 085813061961

How to Cite: Rosyid, N. U., Budiaman, B., \& Hasanah, U. (2019). Improving coastal children eco-literacy in environmental learning through mangroves storytelling. Formatif: Jurnal Ilmiah Pendidikan MIPA, 9 (3): 229-244. http://dx.doi.org/10.30998/formatif.v9i3.3651

\section{INTRODUCTION}

In the last decade environmental problem has been the much intention issues in many academic forums especially in Indonesia following to various natural disasters such as Tsunami, landslides, floods, storms, rain, even heat, and drought. All these events are natural phenomena which are closely related to the human activity. The impacts of natural disasters are invaluable either economically, psychologically, and socially in community life (Budiaman, Wesnina, \& Muhammad, 2016). Serang coastal communities experience problems because of the mangrove ecosystem damaged. Degradation of mangrove ecosystems results the abrasion. According to (Banten Province Environment 
Formatif: Jurnal Ilmiah Pendidikan MIPA

Vol. 9, No. 3, September 2019, pp. 229-244

p-ISSN: 2088-351X

e-ISSN: 2502-5457

DOI: http://dx.doi.org/10.30998/formatif.v9i3.3651

and Forestry Ministry, 2017) Serang coastal residents have lost 300 hectares of land because of abrasion. In addition, the destruction of the mangrove ecosystem in parts of the Serang coast caused the absence of protective coastal areas to mitigate disasters. For example, the Sunda Strait tsunami that occurred caused a very significant destructive impact and caused a lot of casualties. (The National Disaster Management Agency, 2018) said the Sunda Strait tsunami caused 437 deaths, 14,059 people were injured and 33,721 people were displaced by the Sunda Strait tsunami caused by underwater avalanches from the Krakatoa volcanic eruption.

Mangroves have an important role in protecting coastal areas, especially on the coast of Serang - Banten, which has high potential for disasters so that their existence must remain sustainable (Alimuna, 2017). In fact, the Serang coast experienced severe mangrove degradation. Based on data from the (Banten Province Marine and Fisheries Ministry, 2017) the area of mangroves in Banten has decreased dramatically by $67 \%$, leaving only 721.08 ha and most of them are in a damaged condition. The damage of mangrove area on the coast of Serang is largely caused by various human activities in the use of unsustainable mangrove areas for various purposes such as fuel wood needs, relocation into aquaculture land, and settlements (Onrizal, 2017). Unwise use of mangrove activities impacts the low level of education of coastal communities, especially about mangrove conservation (Alimuna, 2017).

Solutions through curative actions by infrastructure such as the construction of wave breakers, the construction of dikes and the installation of tsunami detectors to prevent abrasion and tsunamis are very important, but a sustainable solution is needed through preventive actions by providing understanding to the coastal community about sustainable mangrove ecosystem conservation through education (Kusmana, 2015). Education is an effective means of raising awareness of environmental preservation (Rusmawan, 2017). Environmental education aims to produce citizens who have knowledge of environmental biophysics and related problems, realize how to overcome these environmental problems, and motivate them to find the best solutions (Russo, Rica, $\&$ Rica, 2013). So the formal education system is responsible for the sustainability of environmental education (Karyanto, Prayitno, Sajidan, \& Suwarno, 2014). Understanding of ecological principles and living according to ecological principles in organizing and building together human life on this earth in and to create a sustainable society needs to be instilled early on especially since elementary school (Nugraha, 2015). Elementary school student in their late childhood begin to enter the formal operational stage. According to (J.W. Santrock, 2007) in this stage, individuals move through concrete experiences and think in abstract and more logical ways. As part of their ability to think abstractly, they develop images of ideal situations. To increase environmental awareness, it is necessary to develop "ecological literacy" or "eco-literacy" as an effective approach in the implementation of environmental education in elementary schools by instilling an ideal ecological situation for elementary school children (Sapanca \& Etmagusti, 2012).

Eco-literacy is a new paradigm that aims to increase the ecological awareness of society (Capra, 2007). Eco-literacy seeks to introduce and renew people's understanding of the importance of global ecological awareness, in order to create a balance between people's needs and the Earth's ability to sustain them (Ride, Rewer, Erkowitz, Iteracy, \& $\mathrm{Al}, 2013)$. Eco-literacy has aspects of the eco-pedagogical and ethno-pedagogic include local wisdom values in folklore for classroom learning activities. Through the two pedagogical methods mentioned above, student eco-literacy can be developed in the learning process. Local wisdom can be explored by incorporating stories about the surrounding community into the learning process (Supriatna, 2016). 
Formatif: Jurnal Ilmiah Pendidikan MIPA

Vol. 9, No. 3, September 2019, pp. 229-244

p-ISSN: 2088-351X

e-ISSN: 2502-5457

DOI: http://dx.doi.org/10.30998/formatif.v9i3.3651

One of the learning methods that able to explore the ability of eco-literacy through stories based on local wisdom is storytelling. Based on research (Yulianti, 2014) it is known that storytelling can develop a caring environment character that is conservation-minded for early childhood. Storytelling as learning method was needed because it can explore students of environmental awareness through stories developed by each character. The moral message conveyed in storytelling can make students better understand the environment in a fun way (Mitchell, 2015). Hadzigeorgiou \& Judson (2017) in their research said that it is known that storytelling can develop an environmental awareness as the character that is conservation-minded for early childhood. Through storytelling about mangroves, children will get knowledge about mangroves so that they can increase their eco-literacy capacity.

Based on the results of observation at SDN Cerocoh located on the coast of Serang, it is known the fact that the learning media used as facilitators in science learning on the theme of the environment is still limited to textbooks and worksheet. The learning method is still dominated by lectures. The application of conservative methods in learning science, especially about the environment by teachers makes learning boring. The teacher's way of learning that dominates of the lessons in terms of giving gifts of scientific facts caused a lack of creativity and children may gradually lose interest in learning science because they believed that science is boring and difficult to understand (Mitchell, 2015). The innovation learning method specifically for environmental education that develops the eco-literacy of student about mangroves are also not yet available. Based on the observation, it is important to implementation alternative learning method used mangrove storytelling to improve student eco-literacy about mangrove conservation in SDN Cerocoh - Serang.

Supporting facts from previous studies about the importance of eco-literacy in learning have been published. (Nurfajriani, Azrai, \& Sigit, 2018) stated that there is a relationship between eco-literacy and pro-environment behavior in middle school students. Based on Nurfajriani's (2018) study, the position of the research to be conducted by researchers is to try to find alternative learning method to improve the eco-literacy of students at SDN Cerocoh on the coast of Serang in order to have pro behavior towards the surrounding mangrove ecosystems. Research on eco-literacy in science learning has also been examined by (Adawiah \& Esa, 2014) in junior high schools in Malaysia and the results show that student eco-literacy can be developed in science learning especially in the concept of environment. This support the research for the development of learning method use mangrove storytelling that can improve the eco-literacy students for learning environmental concepts but will be applied at the elementary school level with thematic learning. (Karlina, Degeng, \& Amirudin, 2017) conducted a study on eco-literacy in junior high school students to manage trash Another study was conducted by (Pitman \& Daniels, 2016) who made the development of eco-literacy instruments in the community in Australia. (Hadzigeorgiou \& Judson, 2017) also conducted research on effectiveness of storytelling for raising environmental awareness in young students. However, there has been no research on the implementation of storytelling about mangroves to improve the eco-literacy of coastal children in elementary school.

Based on this background, it is important to conduct research on the application of mangroves storytelling to increasing the eco-literacy of coastal children at SDN Cerocoh, Serang - Banten. This paper analyzes the research status and output information about eco-literacy of coastal children in SDN Cerocoh through mangrove storytelling as learning method. Reseach objective of this paper was to determine increasing the level of eco-literacy of coastal children by using storytelling about the role of mangroves in SDN Cerocoh, Serang - Banten. It is hoped that the results of this study can be used as a 
Formatif: Jurnal Ilmiah Pendidikan MIPA

Vol. 9, No. 3, September 2019, pp. 229-244

p-ISSN: 2088-351X

e-ISSN: $2502-5457$

DOI: http://dx.doi.org/10.30998/formatif.v9i3.3651

reference in applying mangrove storytelling to improve the eco-literacy capabilities of coastal children in other regions of Indonesia so that coastal children get environmental education learning effectively.

\section{METHOD}

This research held in SDN Cerocoh - Banten September until November 2018. The population was all of coastal student in SDN Cerocoh. The sample was students in $3^{\text {rd }}$ Grade consist of 30 students. The technique sampling used by researcher was purposive sampling according to curriculum that thopic of environment for science subject available in first semester $3^{\text {rd }}$ grade which also mix by the topic storytelling for Indonesian language subject in thematic learning.

The researcher applied Classroom Action Research (CAR) as research methodology to conduct the research. In this research, it used participatory class action research, real science teacher act as observer who observed the researcher and the student activities when the teaching and learning takes place. Meanwhile, the researcher act as the practitioner who applied Mangrove Storytelling Media during the teaching and learning process. Before teaching, the researcher prepared the lesson plan. The researcher was also interview sciences teacher to know the problems are faced by students in the class to study about environmental integrated subject theme. Since it deals with the classroom setting, this study was directed to know the eco-literacy of coastal children inorder to find out the solution to the classroom problems in teaching environmental education by using mangrove storytelling media. To cope with the classroom's problem to increasing ecoliteracy, the researcher applied mangrove storytelling media during the teaching and learning process.

The design of CAR in this research used a cycle process, which consists of six steps, adopted from (Kemmis \& Taggart, 2010) as mentioned as follows: 1) Planning change, 2) Acting and observing the process and consequences of the change, 3) Reflecting on these processes and consequences, 4) Re-planning, 5) Acting and observing again, and 6) Reflecting again.

Below was example of diagram process's CAR design that was used by the researcher that is taken from (Kemmis \& Taggart, 2010) as mentioned as follows:

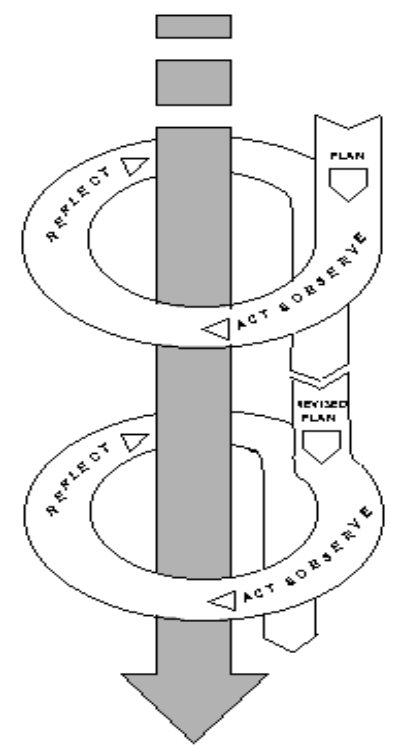

Figure 1. The Cycle of Participatory Action Research (Kemmis \& Taggart, 2010) 
Formatif: Jurnal Ilmiah Pendidikan MIPA

Vol. 9, No. 3, September 2019, pp. 229-244

p-ISSN: 2088-351X

e-ISSN: 2502-5457

DOI: http://dx.doi.org/10.30998/formatif.v9i3.3651

The research has cycles, the cycle was stopped when the condition of the class was stable or the class was accustomed to mangrove storytelling and the data showed eco-literacy improvement in indicator of knowledge, skill, and attitude above

The picture above showed that first, before did action, the researcher has to plan first carefully the kind of actions. Second, after planed drawn well, the researcher acted and observed by the teacher. Third, while the action and observation was done, the researcher observed the reflection process. Forth, based on the observation result, then the researcher reflected based on action that was done. If the result shows it needed to revision of the action, so the action planning needed to be refined again for the subsequent action undertaken in order to not just repeat what was done previously. So on until the problem can be solved optimally investigate.

Data collection technique in this research did qualitatively (experienced-based) and quantitatively (number based). The qualitative data consisted of observation and documentation. On the other side, the quantitative data were used pre-test and posttest.The completely explanation as follows:

1. Test

The researcher used 15 multiple choice question that consist of 5 question about knowledge about mangrove, 5 question about skill of development mangrove in sustainable way and 5 question about attitudes towards mangrove conservation to collect the data and there were two tests in this research pre-testused to know the students achievement in eco-literacy before the implementation of cycle, post-test Iused to know the students achievement in eco-literacy after the implementation of cycle 1 and post-test IIused to know the students achievement in eco-literacy after the implementation of cycle 2 . The following below is grid of eco-literacy question:

Table 1. Grid of Eco-literacy Test Questions

$\begin{array}{ll}\text { Field of Study } & \text { : Natural Sciences } \\ \text { Theme } & : \text { My environment } \\ \text { Class } & : \text { III } \\ \text { Semester } & \text { : I }\end{array}$

Basic Competency:

- Understanding the condition of the surrounding environment and efforts to preserve the environment

\begin{tabular}{|c|c|c|c|c|}
\hline No & Indicator & Aspect & $\begin{array}{l}\text { Number of } \\
\text { Item }\end{array}$ & $\begin{array}{c}\text { Total of } \\
\text { Item }\end{array}$ \\
\hline 1. & $\begin{array}{lr}\begin{array}{l}\text { Students can } \\
\text { mangrove }\end{array} & \begin{array}{l}\text { describe the } \\
\text { ecosystem }\end{array} \\
\text { appropriately } & \end{array}$ & $\begin{array}{l}\text { Knowledge about } \\
\text { mangrove }\end{array}$ & 1,4 & 5 \\
\hline 2. & $\begin{array}{l}\text { Students can provide } \\
\text { examples of the benefits and } \\
\text { roles of mangrove } \\
\text { ecosystems for coastal areas }\end{array}$ & & $2,3,5$ & \\
\hline 3. & $\begin{array}{l}\text { Students are able to } \\
\text { demonstrate how to preserve } \\
\text { and utilize mangroves } \\
\text { sustainably }\end{array}$ & $\begin{array}{ll}\begin{array}{l}\text { Skill } \\
\text { development }\end{array} & \text { of } \\
\text { mangrove } & \text { in } \\
\text { sustainable way } & \end{array}$ & $6,7,8,9,10$ & 5 \\
\hline 4. & $\begin{array}{l}\text { Students show a desire to be } \\
\text { involved in the conservation } \\
\text { of mangroves }\end{array}$ & $\begin{array}{l}\text { attitudes towards } \\
\text { mangrove } \\
\text { conservation }\end{array}$ & $\begin{array}{l}11,12,13,14, \\
15\end{array}$ & 5 \\
\hline & 15 \\
\hline
\end{tabular}


Formatif: Jurnal Ilmiah Pendidikan MIPA

Vol. 9, No. 3, September 2019, pp. 229-244

p-ISSN: 2088-351X

e-ISSN: 2502-5457

DOI: http://dx.doi.org/10.30998/formatif.v9i3.3651

2. Observation

Observation in this research was used to know the process of improving students' eco-literacy through Mangrove Storytelling Media. The researcher got the data about implementation of learning using mangrove storytelling by teacher. The observation sheet is consisted of 10 checklist items about the mangrove storytelling media implementation in learning activity. The following below is a grid of teacher observation sheets :

Table 2. Teacher Observation Grid

\begin{tabular}{|c|c|c|c|}
\hline $\begin{array}{l}\text { Component } \\
\text { assessed }\end{array}$ & $\begin{array}{l}\text { The sub component } \\
\text { assessed }\end{array}$ & $\begin{array}{l}\text { Item } \\
\text { Number }\end{array}$ & $\begin{array}{c}\text { Item } \\
\text { Amount }\end{array}$ \\
\hline \multirow{4}{*}{$\begin{array}{l}\text { Learning } \\
\text { Science with } \\
\text { environmental } \\
\text { themes } \\
\text { use } \\
\text { mangrove } \\
\text { storytelling }\end{array}$} & $\begin{array}{l}\text { Teacher present material outline } \\
\text { about the coastal environment } \\
\text { around and mangrove } \\
\text { ecosystems }\end{array}$ & 1,2 & 2 \\
\hline & $\begin{array}{l}\text { The teacher guides a group of } \\
\text { students to read the mangrove } \\
\text { storytelling properly and } \\
\text { correctly with student } \\
\text { representatives reading a } \\
\text { mangroves storytelling in front } \\
\text { of the class }\end{array}$ & $3,4,5$ & 3 \\
\hline & $\begin{array}{l}\text { The teacher explores students to } \\
\text { understand the mangrove } \\
\text { ecosystem in accordance with } \\
\text { the tale of mangroves from the } \\
\text { start of the mangrove species, } \\
\text { the benefits of mangroves, and } \\
\text { how to preserve mangroves }\end{array}$ & $6,7,8,9$ & 4 \\
\hline & $\begin{array}{l}\text { The teacher gives appreciation } \\
\text { to students }\end{array}$ & 10 & 1 \\
\hline \multicolumn{3}{|c|}{ Total } & 10 \\
\hline
\end{tabular}

3. Documentation

Documentation used to know the brief information when the teacher teaching learning process. Documents might include information statements, the materials book, photo, and lesson plan.

Technique of Data Analysis

1. Quantitative Data Analysis Technique

The researcher used some formula to find out students' Improving Students eco-literacy through Mangrove Storytelling Media in analyzing data of quantitative, to find out the mean score of test, the researcher calculated the average score by using the average score by using the formula as follow:

Where :

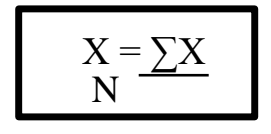

$\mathrm{X}$ : Mean Score

$\sum X \quad:$ The sum of all scores

$\mathrm{N} \quad$ : The total of number of subject (Arikunto, 2012)

Percentage of students' frequency by using formula as follow:

$\mathrm{P}=\frac{\mathrm{F} \times 100 \%}{\mathrm{~N}}$ 
Formatif: Jurnal Ilmiah Pendidikan MIPA

Vol. 9, No. 3, September 2019, pp. 229-244

p-ISSN: 2088-351X

e-ISSN: 2502-5457

DOI: http://dx.doi.org/10.30998/formatif.v9i3.3651

Where :

$\mathrm{P} \quad$ : Percentage

F : : Frequency of the students

$\mathrm{N} \quad$ : Total number of the students

(Hatch and Farhady, 1982)

Score Interpretation :

Score $0 \%-20 \%=$ Very Low

Score $21 \%-40 \%=$ Low

Score $42 \%-60 \%=$ Average

Score $61 \%-80 \%=$ High Enough

Score $81 \%-100 \%=$ High

(Riduwan, 2009)

2. Qualitative Data Analysis Technique

In qualitative research, the data usually analyzed descriptively. In analyzing data, the researcher used Maxtrix Analysis of Miles and Huberman in Sugiyono (2015). The data were divided into the data reduction, data display, and conclusion drawing/verification.

\section{a. Data Reduction}

The first step in analyzing the data of Matrix Analysis was the data reduction. The data reduction referred to the process of selecting, focusing, simplifying, and transforming the data that appear in written up field notes or transcriptions. In this research, it used to abstracting the result of the data observation and the test in order to get clearly description about the data and help the researcher for the next step of data collecting. Data reduction was done by giving code certain aspects.

\section{b. Data display}

After data reduction, the next step was displaying the data. Generically, a display was an organized, compressed assembly of information that permits conclusion drawing and action. In this research, the researcher displayed the data of observation and test in order help to understand what happened and planned the next work or action based on that understanding. In qualitative research, data display was in the form of short description, chart, connection between categories, flow chart, etc.

c. Conclusion Verification

The last step of Matrix Analysis by Miles and Huberman in (Sugiyono, 2015) is conclusion verification. This step is to describe the data of observation and test into conclusion, which is will be easy to understand by the researcher and the other.

\section{RESULT AND DISCUSSION}

\section{Result}

Introduction of Activities

This action research conducted at the third grade of SDN Cerocoh. It is located in Jl. Ps. Ikan Domas Domas Village, Serang - Banten.

Before starting the cycles, the researcher started interview to science teacher of SDN Cerocoh. Based on the researcher observation and interview, the teacher used the conventional method in teaching environmental education in thematic science theme. It could be predicted that the students were not interested and motivated in learning science. They need interesting media to encourage them in learning about environment better. To know the students background in eco-literacy before giving the treatment, the researcher gave pre-test to the students. Pre-test was true-false questions which consisted in 20 
Formatif: Jurnal Ilmiah Pendidikan MIPA

Vol. 9, No. 3, September 2019, pp. 229-244

p-ISSN: 2088-351X

e-ISSN: 2502-5457

DOI: http://dx.doi.org/10.30998/formatif.v9i3.3651

questions. As result the score was far from perfection, the average score of students score was 48,52 .

The classroom action research was started from September 10th until 28th 2018. The schedule of meeting was twice a week on Monday and Wednesday. The researcher was conducted in class III which consisted of 30 students. The researcher implemented the research based on the schedule that had been arranged by the researcher. The research conducted into two cycles. Each cycle consisted of two meetings. The data above shows that the average score of students was 48.52. It means that the eco-literacy of the students of students before treatment was very low. Furthermore, this score became the basic of the research to conduct classroom action research and gave a new interesting media in teaching mangrove to improve students' eco-literacy. Therefore, it was one of the efforts to improve their mangrove eco-literacy of coastal students in SDN Cerocoh.

Result of Cycle I

The research started the cycle 1 on 10th until 19th September 2018 which consisted of two meetings. It was described as follow:

1. Planning

Before the researcher did the cycle one, the research prepared lesson plan for two meetings, camera for documentation, and observation sheet to record activities during teaching and learning process in classroom. The researcher designed lesson plan about learning environmental education by using Mangrove Storytelling Media.

This research plan is a plan that is systematically arranged and structure the plan must point forward. Researchers and collaborators, namely teachers, set alternative actions to be carried out through the mangrove storytelling in an effort to increase the eco-literacy of students on environmental themes through the following matters:

a. The researcher and the teacher discussed to identify the problem which appears related to learning the theme of the environment

b. The researcher gave the idea to use the mangrove storytelling media to be applied in learning environmental themes

c. The teacher and researcher agreed to solve the problem of learning the environment theme through the mangrove storytelling to improve the ecoliteracy of students

d. Researchers provide input and discuss with the teacher to prepare learning plans and materials to be used

e. The teacher checks the lesson plan and the material to be taught with discussed first with the researcher.

2. Acting

At the first meeting of cycle 1, the researcher explained about the coastal environment and mangrove as one of the important component in coastal environment that can be found easily in around them. After that, the researcher distributed picture about kind of mangroves in character animation form in subject integrated theme our environment; Rhizo as Rhizopora sp., Avi as Avicennia sp., Brugu as Bruguiera gymnorhiza, and Sonne as Sonneratia sp. Students were divided into five groups which consist of 6 students for each group. Students in groups read Mangrove Storytelling titled "Rhizopora yang Kuat". This mangrove tale tells about Rhizo who is considered to have a strange root compared to the other three mangrove friends. besides, Rhizo also does not have fruit that can be consumed by residents such as other types of mangroves. The fishermen did not like Rhizo roots which were considered to damage the ponds. Rhizo felt sad and isolated until one day a high wave called the Cyclone came to destroy the coastal fishermen's village but was stopped by the roots of mangroves Rhizopora. In the end coastal residents realized that every mangrove had benefits and must be protected. 
Formatif: Jurnal Ilmiah Pendidikan MIPA

Vol. 9, No. 3, September 2019, pp. 229-244

p-ISSN: 2088-351X

e-ISSN: 2502-5457

DOI: http://dx.doi.org/10.30998/formatif.v9i3.3651

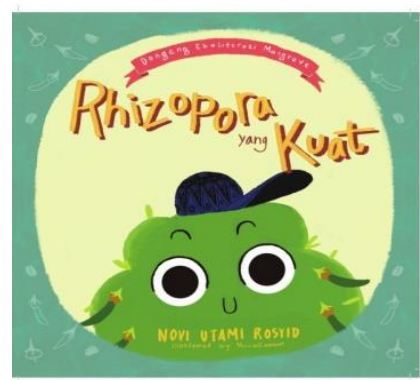

Figure 2. Mangrove Storytelling Book

After that, they create short simple descriptive sentences about the character mangroves in Mangrove Storytelling Media based on their physical appearance. They had to fill the worksheet and discuss to finish them in 20 minutes. In this meeting, some students gave good interaction to the teacher explanation and they were enthusiastic to character animation mangrove in mangrove storytelling media.

At the second meeting, the researcher asked a few question related to the topic about the story in mangrove storytelling. Then, the researcher recalled the explanation of character and function of mangrove in the story. And then, the teacher asked the student to draw character of mangrove that they ever read mangrove story telling "Rhizopora yang Kuat".

After that, each student in group shared their picture with simple descriptive sentences about character of mangrove in mangrove storytelling media. The students look happy to learn about mangrove using mangrove storytelling media.

3. Observing

Based on result, the observation in first meeting of cycle 1, Mangrove Storytelling Media made students interactive in learning. At that time, the observer saw situation in the classroom was good enough, but there were a few students were still noisy and passive to response what the teacher asked. The observer also saw the interaction while teaching and learning process was good enough. Students could understand the meaning the part of describing character mangrove in mangrove storytelling media.

The second meeting describe that the learning process was good enough. The observer found the students more attractive in learning situation and really enjoyed drawing character of mangrove they like. The observer could see them enthusiastic than before. The observer also saw students look happy to sharing information about character of mangrove. The teachers as guide just helped the students who have difficult. In the end of teaching learning process, the researcher would be gave some questions to asked about their knowledge by asking about what have learned. The researcher also gave them the first post-test to measure their eco-literacy in understanding the mangrove. The test was true \& false test which consists of 20 questions. As the result of test which was better than their result pre-test. Their score increased even though a few students were still stable of their score. The data above showed that the average score of students was 68.94. It means that the achievement of the students' post-test 1 was increase than pre-test.

4. Reflecting

The process of teaching mangrove with mangrove storytelling media in cycle one was good. There was improvement around 20.42 points between pretest and first post test in cycle 1 but that point but the value has not been maximized because it has not yet reached the minimum standard eco-literacy that must be achieved, that is equal to 70 based on development instrument by Pitman (2016). 
Formatif: Jurnal Ilmiah Pendidikan MIPA

Vol. 9, No. 3, September 2019, pp. 229-244

p-ISSN: 2088-351X

e-ISSN: $2502-5457$

DOI: http://dx.doi.org/10.30998/formatif.v9i3.3651

Table 3. Calculation of Students' Mangrove Eco-literacy

Test Score Average Improvement

\begin{tabular}{|c|c|c|c|}
\hline Test & $\begin{array}{c}\text { Scor } \\
\text { e }\end{array}$ & Average & Improvement \\
\hline Pre-Test & 1650 & 48.52 & - \\
\hline $\begin{array}{c}\text { Post- } \\
\text { Test }\end{array}$ & 2344 & 68.94 & 20.42 \\
\hline
\end{tabular}

Submission of material has not been too maximal in cycle 1 . It is evidenced by the assessment of observations of 73.50. It happened because the researchers had not mastered the classroom condition so that when they read the story of the mangrove, some students did not listen too much.

The thing that must be corrected in the next cycle is the provision of class pre-condition treatments such as with a simple game to ensure that students are ready to receive lessons.

The result of the first post-test than reached in the cycle 1 had increased from 48.52 in the pre-test to 68.94 in first post test. After the researcher conducted cycle 1 and got the result of test, the researcher found difficulties of students' to understanding about the role of mangrove in ecosystem function. Although the average of the first post-test were up than pre-test, but there were a few students who missed it. It happened because they only paid attention to researcher to giving explanation the material and sometime the students talk in the classroom. For this problem, the researcher revised the plan in cycle 2.

\section{Result of Cycle II}

The research started the cycle II on September 26th until 28th 2018 which consists of two meetings. It described as follow:

1. Planning

To make students easily in learning of mangrove, the teaching learning process in cycle 2 used mangrove props from cardboard as character illustration to make them easier to understand mangrove story telling. The materials in this cycle were about the role of mangrove and how to conserve it. The researcher also prepared camera for documentation, and observation sheet to record activities during teaching and learning process in classroom.

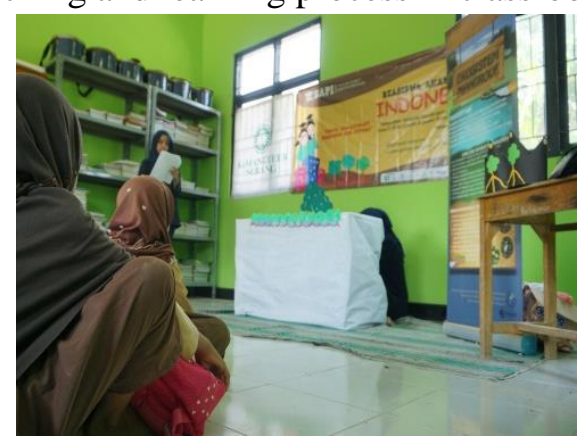

Figure 3. Mangrove Storytelling with Mangrove Props

\section{Acting}

The first meeting of cycle 2 , before giving the material, in the first teaching, the researcher called the students' name one by one on the attendance list. The researcher gave warming up before study to improved students attention and motivation in the class. To memorize the material before, the researcher explained the previous material in last meeting and also ask students to memorize the character of mangrove that have been learn before. 
Formatif: Jurnal Ilmiah Pendidikan MIPA

Vol. 9, No. 3, September 2019, pp. 229-244

p-ISSN: 2088-351X

e-ISSN: $2502-5457$

DOI: http://dx.doi.org/10.30998/formatif.v9i3.3651

At while teaching, the researcher told about mangrove with the illustration mangrove props. After that, the students divided into five groups each groups consists into 6 students. The researcher taught the student how to plant the mangrove and the student practicing together. In this meeting, some students gave good attention to the researcher's explanation and they were enthusiastic in studying about mangrove.

The second meeting, the researcher began the class by repeating the previous material about the role of mangrove. The students still remembered the last material, it could be seen from students responded. Some students were enthusiastic to answer the researcher questions but some students still ashamed to respond.

The researcher started the material about how to conserve mangrove. After that, the students divided into five groups each groups consists of six students. The researcher gave training about how to plant mangrove. After that, the researcher reviewed all of the materials that were done in first until last meeting to improve students' eco-literacy about mangrove.

Second post-test was done on Monday September 28th 2018 which was started at 08:00 a.m. The result of post-test 2 was very good. Almost students' score were increased highly. The average score of students was 87,17 . It means that the students' post-test 2 achievement was increased than pre-test 1.

3. Observing

Based on the result of observation in first meeting of cycle II on September 26th 2018, with allocation 2x40 minutes which started from 08:00 a.m., the observer saw the researcher explanation the material was clearly and good enough. The observer also saw when the researcher explained the mangrove storytelling, the situation was good. The situation was quite because the students paid good attention. So, the observer concluded the teaching and learning process was running well. Students were enthusiastic when the students listened about mangrove storytelling with mangrove illustration props.

The second meeting of the cycle 2 was conclude on September 27th 2018 at 08:30 a.m. with allocation $2 \times 40$ minutes. The observer saw the students more enthusiastic and their motivation was increase than before. The students also easy to understood the researcher explanation about how to plant mangrove.

4. Reflecting

The process of teaching environmental education about mangrove in cycle two was very good. The changing of situation began at cycle two in the first meeting when researcher using mangrove illustration props to helped students more easily understanding the mangrove storytelling. The students were familiar with the media, it made them enjoy.

Table 4. Eco-literacy Improvement (\%)

\begin{tabular}{|l|l|l|l|}
\hline & Score & Percent & Improvement \\
\hline Pre-Test & 48.52 & $48.52 \%$ & - \\
\hline Post Test 1 & 68.94 & $68.94 \%$ & $20.42 \%$ \\
\hline Post Test 2 & 87.17 & $87.17 \%$ & $18.23 \%$ \\
\hline
\end{tabular}

According to the table 4.3, the result of post-test 2 that reached in cycle 2 had increased from 68.94 in the first post-test to 87.17 in the second post-test, almost of students could understand about kind of mangrove, role of mangrove, and how to conserve the mangrove. Based on the observation in the class along the research, the teacher never teaching about mangrove and the teacher used old teaching style which was 
Formatif: Jurnal Ilmiah Pendidikan MIPA

Vol. 9, No. 3, September 2019, pp. 229-244

p-ISSN: 2088-351X

e-ISSN: 2502-5457

DOI: http://dx.doi.org/10.30998/formatif.v9i3.3651

not using storytelling media in environmental education theme in thematic science subject. It could be predicted that the students did not interested in learning about environment. To know the students background in environmental understanding the researcher gave eco-literacy pretest to the students. Most of students score was 48, 52 the lowest was 28 and the highest was 70 .

In cycle one, the researcher gave pre-test before treatment and gave the post-test after treatment. The researcher did not explain the material at the pre-test. So, the result of pre-test was very low than the post-test 1 after treatment. From the cycle 1 , the students learned the kind of mangrove by using mangrove storytelling media to make easier in memorizing mangrove species because the student learned the mangrove species in character cartoon. After cycle 1, the average score in post-test 1 was 68.94. The improvement was became $20.42 \%$. The result in of post-test 2 in cycle 2 showed the average score of students' eco-literacy increased 18, 23\% from 68.94 in the post-test 1 to 87,17 in the post-test 2.

Based on the data from the students' score, the researcher made the average of score from the cycle 1 to the cycle 2 . The researcher drew the students' improvement in the following and diagram:

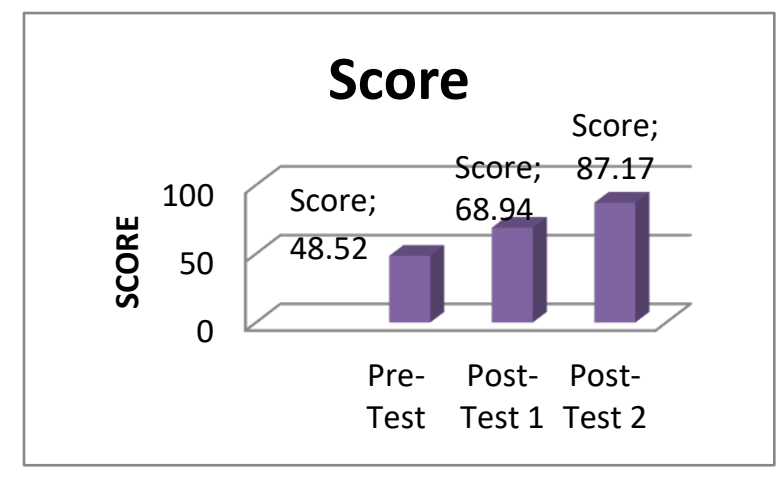

Figure 4. Students' Eco-literacy Improvement

Based on diagram above, the researcher concluded that there was the improvement of students' average score in student's eco-literacy mangrove by using Mangrove Storytelling Media. The improvement started from the first post-test in cycle 1, the average score was improved better than pre-test of students' eco-literacy. It was improved $20.42 \%$ then after conducting cycle two, there was improvement in students' score, the score was better than the average score in post-test one, it was improved $18.23 \%$. The researcher concluded that were significant improving students' eco-literacy through Mangrove Storytelling Media after having some treatments in each cycle.

The improvement of student's eco-literacy can also be seen from each indicator of eco-literacy that also increase including knowledge about mangroves, the skill of development of mangroves in sustainable ways and attitudes towards mangrove conservation. The data about improvement student's eco-literacy in each indicator can be seen in following diagram: 
Formatif: Jurnal Ilmiah Pendidikan MIPA

Vol. 9, No. 3, September 2019, pp. 229-244

p-ISSN: 2088-351X

e-ISSN: 2502-5457

DOI: http://dx.doi.org/10.30998/formatif.v9i3.3651

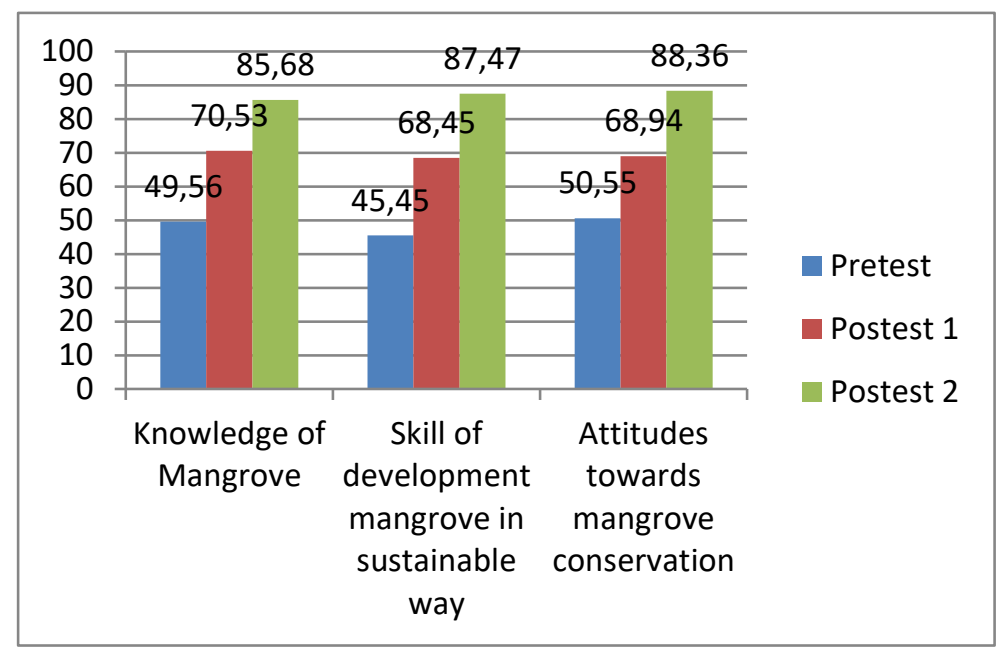

Figure 5. Students' Eco-literacy Improvement in Each Indicator

\section{Discussion}

In the first meeting of the research, the researcher and observer found that almost students were having difficulties in learning mangrove because they never learn about mangrove before. They just know "bakau" and not specific function. Moreover, after giving treatment and explaining the mangrove materials about the kind of mangrove, the role of mangrove, and the in each cycle, they could understand about the point the materials. The improvement could increase step by step. It could be shown by the score they got. It could be shown by the score they got it. It could increase from pre-test to the post-test two.

Improving the eco-literacy of students proved after the implementation of environmental education learning about mangrove conservation used the mangrove storytelling in accordance with the theory. Storytelling can be used as effective learning media to capture their interest in learning science. In particular, storytelling as learning media for environmental education can be used to challenge young explore environmental issues, reflect on their experiences of nature, and test their beliefs about humans built with humans and nature (Hadzigeorgiou \& Judson, 2017). When we tell stories, we take advantage of the natural tendency for humans to find connections to share knowledge, experience and wisdom. In addition, storytelling invites certain closeness as part of the process of expression, and the act of sharing with others. Storytelling required us to realize the character, place, and experience that we share and communicate (Mohktar, 2010). This is needed so that participants can understand, feel, and implement good values. Character education developed in environmental education is a character that cares about the environment which can make a child become highly eco-literacy or said to be "literate to the environment". Eco-literacy requires a level of environmental awareness, eco-literacy has gone beyond mere identification of plant and animal species for understanding and knowledge of the relationship of ecology and interactions and the long-term effects of human actions on the environment (Fortino \& Masters, 2014). Ecoliteracy aims to increase the ecological awareness of the community. As stated by Capra (2007) explains that eco-literacy seeks to introduce and renew people's understanding of the importance of global ecological awareness, in order to create a balance between people's needs and the earth's ability to sustain them. By including the eco-literacy of mangroves into the process of environmental education for coastal communities, especially the younger generation, community awareness will be formed towards their environment so that the community is more easily directed to carry out mangrove conservation activities. 
Formatif: Jurnal Ilmiah Pendidikan MIPA

Vol. 9, No. 3, September 2019, pp. 229-244

p-ISSN: 2088-351X

e-ISSN: 2502-5457

DOI: http://dx.doi.org/10.30998/formatif.v9i3.3651

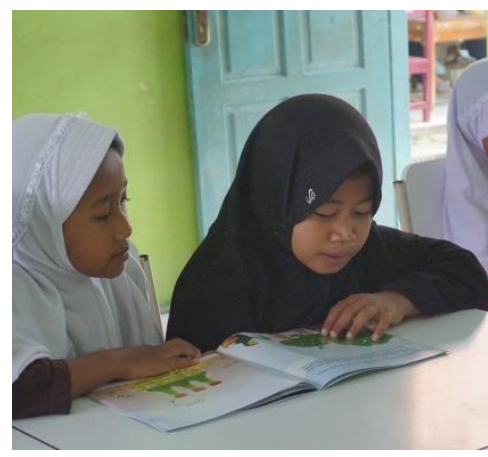

Figure 6. Learning with Mangrove Storytelling Media

The application of environmental education by using the story of mangroves to improve the eco-literacy of mangrove children on the coast of Serang is the best solution to educate coastal communities starting from the younger generation who do not yet have an interest so that it is easier to teach them conservation values. The fairy tale reading is equipped with an illustration model made of cardboard, thus adding to the attraction for children to listen to the fairy tale of the mangrove. During the fairytale reading in 3rd grade SDN Cerocoh, students were very enthusiastic and they were very curious about the main character of the mangrove in the story

Finally, the teaching of improving students' eco-literacy the coastal children though Mangrove Storytelling Media at Third Grade Students in SDN Cerocoh had been proven to improve the students'eco-literacy. The teacher should apply interesting media in teaching about mangrove, eco-literacy was main important in environmental education to rise the environmental awareness of coastal children.

\section{CONCLUSION}

The Based on formulation of the problem, the result and discussion of the analysis, the process of improving eco-literacy with Mangrove Storytelling Media in teaching mangrove in environment theme included each of cycle there two meetings by applying Mangrove Storytelling Media for teaching mangrove. Mangrove Storytelling Media could help the students understanding about mangrove. It could be seen from the students' progress in test and in every meeting. It can be seen from the average score of pre-test was 48.52, the average student's score in cycle 1 was 68.94 points, in cycle 2 the students got improvement point was 87.17 about environment especially mangrove and also to help students improve their eco-literacy in a fun way.

\section{REFERENCES}

Adawiah, R., \& Esa, N. (2013). Ecological Literacy among Secondary School Students. Paper Presented on International Conference on Science and Mathematics Education, 11-14 November 2013..

Alimuna, W. (2016). Pengaruh aktivitas masyarakat terhadap kerusakan hutan mangrove di Rarowatu Utara, Bombana Sulawesi Tenggara. https://www.researchgate.net/publication/312042764 Pengaruh Aktivitas Masyara kat_terhadap_Kerusakan_Hutan_Mangrove_di_Rarowatu_Utara_Bombana_Sulawe si_Tenggara

Arikunto, S. (2012). Prosedur Penelitian Suatu Pendekatan Praktik. Jakarta: Rhineka Cipta. 
Formatif: Jurnal Ilmiah Pendidikan MIPA

Vol. 9, No. 3, September 2019, pp. 229-244

p-ISSN: 2088-351X

e-ISSN: 2502-5457

DOI: http://dx.doi.org/10.30998/formatif.v9i3.3651

Banten Province Environment and Forestry Ministry. (2017). Data on the extent of abrasion affected areas in the Banten province. Retrieved from www.menlhk.go.id

Banten Province Marine and Fisheries Ministry. (2017). Data of mangrove extension in Banten Province. Banten.

Budiaman, Wesnina, \& Muhammad, Z. bin. (2016). Baduy local wisdom and environment sustainability. Opcion, $34 \quad$ (15). https://www.researchgate.net/publication/331864869_Baduy_local_wisdom_and_en viromental_sustainability

Capra, F. (2007). Sustainable living, ecological literacy, and the breath of life. Canadian Journal of Environmental Education, 12, 9-18.

Fortino, C., \& Masters, V. (2014). Growing up WILD: Teaching environmental education in early childhood. International Journal of Early Childhood Environmental Education, 2(1), 156-171.

Hadzigeorgiou, Y., \& Judson, G. (2017). Toward more effective storytelling for raising environmental awareness in young students. Journal of Advances in Education Research, 2(1), 12-18.

J.W. Santrock. (2007). Life-span Development. Twelfht Edition. New York: Mc Graw Hill.

Karlina, F., Degeng, I. N. S., \& Amirudin, A. (2017). Ecoliteracy siswa sd dalam kegiatan pengelolaan sampah melalui group investigation berbasis outdoor study. Jurnal Pendidikan: Teori, Penelitian, dan Pengembangan, 2(2017), 991-1002.

Karyanto, P., Prayitno, B., Sajidan, \& Suwarno. (2014). Penguatan modal manusia dan peningkatan literasi ekologi melalui pedagogi spesifik materi:pengembangan model dalam pembelajaran ekologi melalui penelitian ekofisiologi tikus sawah. In Seminar Nasional XI Pendidikan Biologi FKIP UNS. Surakarta: UNS.

Kemmis, S., \& Taggart, R. M. (2010). The Action Research Planner. (D. University, Ed.). Victoria.

Kusmana, C. (2015). Integrated sustainable mangrove forest management. Jurnal Pengelolaan Sumberdaya Alam dan Lingkungan, 5(1), 1-6.

Mitchell, H. J. (2015). Knowledge sharing - the value of story telling. International Journal of Organisational Behaviour, 9(5), 632-641.

Nugraha, R. G. (2015). Meningkatkan ecoliteracy siswa SD melalui metode fieldpengetahuan sosial. Mimbar Sekolah Dasar, 3(2), 60-72. https://doi.org/10.17509/mimbar-sd.v2i1.1322

Nurfajriani, N., Azrai, E. P., \& Sigit, D. V. (2018). Hubungan ecoliteracy dengan perilaku pro-lingkungan peserta didik SMP. Florea: Jurnal Biologi dan Pembelajarannya, 5(2), 63-69. https://doi.org/10.25273/florea.v5i2.3126

Onrizal. (2017). Evaluasi Kerusakan Kawasan Mangrove Dan Alternatif Rehabilitasi Di Jawa Barat dan Banten. USU Digital Library.

Pitman, S. D., \& Daniels, C. B. (2016). Quantifying ecological literacy in an adult western community: The development and application of a new assessment tool and community standard. quantifying ecological literacy. Plos One, 1, 1-18. https://doi.org/10.1371/journal.pone.0150648

Ride, B. B. M. C. B., Rewer, C. A. B., Erkowitz, A. R. B., Iteracy, L., \& Al, M. E. T. (2013). Environmental literacy, ecological literacy, ecoliteracy: What do we mean and how did we get here? Ecosphere, 4(May), 1-20.

Riduwan. (2009). Dasar - Dasar Statistika. Bandung: Alfabeta.

Rusmawan. (2017). Ecoliteracy dalam konteks pendidikan IPS. Sosio Didaktika: Social Science Education Journal, 4(2), 39-50. 
Formatif: Jurnal Ilmiah Pendidikan MIPA

Vol. 9, No. 3, September 2019, pp. 229-244

p-ISSN: 2088-351X

e-ISSN: 2502-5457

DOI: http://dx.doi.org/10.30998/formatif.v9i3.3651

Russo, R. O., Rica, U. D. C., \& Rica, C. (2013). Environmental education and ecoliteracy as tools of education for sustainable development. Journal of Sustainability Education, 4 (May 2014).

Sapanca, P. L. Y., \& Etmagusti. (2012). Efektivitas ekoliterasi dalam meningkatkan pengetahuan, sikap dan perilaku masyarakat mengenai education for sustainable development berbasis tanaman pangan lokal (Studi Kasus Di Kecamatan Bangli). Agrimeta: Jurnal Pertanian Berbasis Keseimbangan Ekosistem, 1 (1), 1-13.

Sugiyono. (2015). Metode Penelitian Kuantitatif, Kualitatif, dan R\&D. Bandung: Alfabeta.

Supriatna, N. (2016). Local Wisdom in Constructing Students' Ecoliteracy Through Ethnopedagogy and Ecopedagogy. In 1st UPI International Conference on Sociology Education (UPI ICSE 2015) (pp. 126-133). Atlantis Press.

The National Disaster Management Agency. (2018). Data on the number of victims of Sunda strait tsunami in Banten Province. Retrieved from www.bnpb.go.id

Yulianti, D. (2014). Pengembangan karakter peduli lingkungan anak usia dini melalui buku cerita bermuatan sains berwawasan konservasi. Jurnal Penelitian Pendidikan, $31(1), 11-18$. 